medRxiv preprint doi: https://doi.org/10.1101/2021.03.23.21254092; this version posted March 26, 2021. The copyright holder for this preprint (which was not certified by peer review) is the author/funder, who has granted medRxiv a license to display the preprint in It is made available under a CC-BY-NC-ND 4.0 International license.

\title{
Reconstructing the COVID-19 epidemic in Delhi, India: infection attack rate and reporting
} of deaths

Margarita Pons-Salort ${ }^{1}{ }^{*}$, Jacob John², Oliver J Watson ${ }^{1}$, Nicholas F Brazeau ${ }^{1}$, Robert Verity ${ }^{1}$, Gagandeep Kang ${ }^{3}$, Nicholas C Grassly ${ }^{1}$

1 MRC Centre for Global Infectious Disease Analysis; and the Abdul Latif Jameel Institute for Disease and Emergency Analytics (J-IDEA), School of Public Health, Imperial College London, UK

2 Department of Community Health, Christian Medical College, Vellore, India

3 Department of Gastrointestinal Sciences, Christian Medical College, Vellore, India

*Corresponding author: m.pons-salort@imperial.ac.uk 
medRxiv preprint doi: https://doi.org/10.1101/2021.03.23.21254092; this version posted March 26, 2021. The copyright holder for this preprint (which was not certified by peer review) is the author/funder, who has granted medRxiv a license to display the preprint in It is made available under a CC-BY-NC-ND 4.0 International license

\begin{abstract}
India reported over 10 million COVID-19 cases and 149,000 deaths in 2020. To estimate exposure and the potential for further spread, we used a SARS-CoV-2 transmission model fit to seroprevalence data from three serosurveys in Delhi and the time-series of reported deaths to reconstruct the epidemic. The cumulative proportion of the population estimated infected was $48.7 \%$ (95\% Crl 22.1\% - 76.8\%) by end-September 2020. Using an age-adjusted overall infection fatality ratio (IFR) based on age-specific estimates from mostly high-income countries (HICs), we estimate that $15.0 \%$ (95\% Crl 9.3\% - 34.0\%) of COVID-19 deaths were reported. This indicates either under-reporting of COVID-19 deaths and/or a lower agespecific IFR in India compared with HICs. Despite the high attack rate of SARS-CoV-2, a third wave occurred in late 2020 , suggesting that herd immunity was not yet reached. Future dynamics will strongly depend on the duration of immunity and protection against new variants.
\end{abstract}

\title{
Main text
}

With just under 150,000 COVID-19 deaths reported in 2020, India has a much lower reported COVID-19 mortality per million people than many other countries, such as Spain, France, the UK and the US. This discrepancy may be partly due to a younger population, but also incomplete documentation of deaths and of COVID-19 as a cause of death ${ }^{1,2}$. Assessing the extent of under-reporting of COVID-19 cases and deaths is essential to estimate the true burden of COVID-19 and likely future trends in transmission.

Multiple SARS-CoV-2 seroprevalence surveys conducted during 2020 in Delhi offer an opportunity to reconstruct the epidemic, assess the completeness of COVID-19 death 
medRxiv preprint doi: https://doi.org/10.1101/2021.03.23.21254092; this version posted March 26, 2021. The copyright holder for this preprint (which was not certified by peer review) is the author/funder, who has granted medRxiv a license to display the preprint in It is made available under a CC-BY-NC-ND 4.0 International license .

reporting and estimate the infection attack rate in one of India's largest metropolitan areas, home to 20 million people. SARS-CoV-2 transmission in Delhi has led to three waves of infection and mortality (Figure 1). At the beginning of the epidemic, all SARS-CoV-2 testing relied on RT-PCR, but since mid-June, antigen-based rapid diagnostic tests (Ag-RDTs), which have a lower sensitivity, have also been used and quickly exceeded the daily number of RTPCR tests (Figure S1). Three serosurveys were conducted in Delhi in July, August and September, sampling individuals over 4 years old, found an age- and sex-adjusted seropositivity rate (uncorrected for test sensitivity and specificity) of $22.8 \%, 28.7 \%$ and $25.1 \%$ respectively (details in Table $\mathrm{S} 1)^{3}$. Although the first serosurvey found a difference between slum and non-slum areas ( $25.3 \%$ vs. $19.2 \%, p<0.001)$, the second did not $(28.9 \%$ vs. $28.8 \%, p=0.94)$, and the third did not report this information.

We developed a SARS-CoV-2 transmission model to estimate the incidence of infection and changes in the reproduction number $(R)$ following implementation of non-pharmaceutical interventions, including lockdowns (Table S2, Figure S2). We used Bayesian Markov Chain Monte Carlo to fit the model to the three seroprevalence surveys and the time-series of reported deaths. The proportion of COVID-19 deaths reported was estimated by comparing reported deaths to those expected based on the age-adjusted IFR. We used estimates of the age-specific IFR based on data from 7 European countries, New York (USA) and Brazil ${ }^{4}$, to give a median age-adjusted IFR for Delhi of $0.39 \%$ ( $95 \%$ prediction interval $0.21-0.85 \%$; this compares with $\sim 1 \%$ in high-income countries with older populations such as the $\left.U K^{5,6}\right)$. Agespecific estimates from early data from $\mathrm{China}^{6}$ and from a meta-analysis in "advanced economies ${ }^{\prime \prime}$ gave a very similar value $(0.39 \%$ and $0.40 \%$, respectively). See the Online Methods for more details of the modelling and inference framework. 
medRxiv preprint doi: https://doi.org/10.1101/2021.03.23.21254092; this version posted March 26, 2021. The copyright holder for this preprint (which was not certified by peer review) is the author/funder, who has granted medRxiv a license to display the preprint in It is made available under a CC-BY-NC-ND 4.0 International license .

Our model fits the data well for both the time-series of deaths (Figure 2a) and seroprevalence survey data (Figure $2 b$ ), except the last serosurvey, where we estimate an increase in seropositivity with respect to the previous survey, instead of a slight decrease. This may be because the observation model does not account for waning antibodies and the possibility of seroreversion. However, the third serosurvey used a different testing kit, which could also contribute to this difference. We estimate that the first peak in incidence of infections was reached on the $31^{\text {st }}$ of May, when there were a median of 294,930 ( $95 \% \mathrm{Crl}$ $143,271-440,702$ ) new infections each day (Figure S4). The incidence at the second peak, reached on the $17^{\text {th }}$ of September, was slightly smaller, with a median of $79,032(95 \% \mathrm{Crl}$ $40,484-109,140)$ new infections per day. Assuming that transmission changes occur at the different changes in interventions and accounting for the depletion of susceptibles, we estimate that the effective reproduction number, $R_{\text {eff, }}$ increased during the relaxations introduced at phase 3 of the lockdown (starting on May 4), then decreased and then increased again in August (Figure 3a), resulting in a median infection attack rate of $48.7 \%$ (95\% Crl $22.1 \%-76.8 \%)$ by the end of September. Since then, Delhi has experienced a large third wave of cases and deaths (Figure 1), therefore suggesting that even with half of the population having been infected, the herd immunity threshold was not yet reached at that time. Interestingly, a serosurvey conducted in January 2021 found a sex- and age-adjusted seroprevalence of $56.1 \%$, reflecting this third wave of transmission and probably indicating a steep increase in the cumulative number of infections.

Using the age-adjusted IFR of $0.39 \%$, we estimate the reporting of deaths to be $15.0 \%$ (95\% Crl 9.3\%-34.0\%) (Figure S5). Repeating the analysis with an age-adjusted IFR of $0.21 \%$, 
medRxiv preprint doi: https://doi.org/10.1101/2021.03.23.21254092; this version posted March 26, 2021. The copyright holder for this preprint (which was not certified by peer review) is the author/funder, who has granted medRxiv a license to display the preprint in It is made available under a CC-BY-NC-ND 4.0 International license

corresponding to the lower bound of the $95 \%$ prediction interval based on age-specific HIC data, ${ }^{4}$ increased the reporting rate to $28 \%$ (95\% $\left.\mathrm{Crl} 18-59 \%\right)$. This low rate of reporting is consistent with other cities in India where seroprevalence surveys suggest substantially greater exposure to infection than that predicted based on reported COVID-19 deaths. For example, comparison of seroprevalence during the first half of July 2020 in Mumbai ${ }^{8}$ with cumulative deaths at that time, gives an approximate estimate of reporting of $21 \%$ (Table S3). This high level of under-reporting may reflect both incomplete or delayed reporting of deaths and a failure to report COVID-19 as a suspected or confirmed cause of death, particularly in the absence of a SARS-CoV-2 test result. However, the extent of underreporting is also dependent on the appropriateness of using an age-specific IFR in India derived from HIC data. The age-specific IFR may be lower in India for a number of reasons. First, the prevalence of comorbidities that increase the risk of severe COVID-19 following infection is somewhat lower in India than in the countries that informed the age-specific IFR estimates (Figure S6) ${ }^{9}$. However, correcting the Delhi IFR to account for the lower prevalence of comorbidities only marginally reduces the age-adjusted IFR (by up to $0.02 \%$ ). Second, a recent study that analysed COVID-19 deaths by age from Mumbai and Karnataka found that the IFR rose less steeply with age than it did in high-income countries ${ }^{10}$. Third, differences in immunity reflecting exposure to a greater number of pathogens (including related coronaviruses) or simply lower frailty among those surviving to older ages in India compared with HICs could theoretically reduce the IFR in older groups, although data supporting these hypotheses are lacking. ${ }^{11,12}$.

Using the reconstructed incidence of infections, we also estimated the probability of detecting COVID-19 cases over time by comparing the number of reported cases to the 
medRxiv preprint doi: https://doi.org/10.1101/2021.03.23.21254092; this version posted March 26, 2021. The copyright holder for this preprint (which was not certified by peer review) is the author/funder, who has granted medRxiv a license to display the preprint in It is made available under a CC-BY-NC-ND 4.0 International license

estimated incidence of symptomatic infections (Figure 4a). The probability of infection detection quickly increased over the last weeks of March, fluctuated until mid-June, and remained relatively constant until the end of September, detecting a median of $7.1 \%$ of all symptomatic infections on average between July 1 and September 30, 2020 (Figure 4b).

This work has some limitations. First, the transmission model is not structured by age, and therefore, does not account for different mixing patterns between age classes and different attack rates by age. Nonetheless, age-structured models have predicted relatively flat infection attack rates across age for $\operatorname{India}^{13}$, consistent with age-stratified seroprevalence estimates $^{3}$. This suggests that any bias in our results from age-specific patterns of mixing and potentially lower attack rates in more susceptible older age groups is likely to be limited. Second, we assume that reporting of deaths has been constant over the study period, but this value might have actually changed over time. Therefore our estimate of reporting represents an average over the study period. Finally, we use estimates of the agespecific IFR from mostly HICs and explore sensitivity to this assumption, including the use of data on comorbidities in India. Further analysis using data from cohort studies or demographic surveillance data in India will help to refine these estimates of the IFR and the exact degree of under-reporting of mortality.

At the time of writing (February 2021), the total number of new COVID-19 cases has been declining in India since mid-September 2020. How much of the country's population has already been infected, and whether the herd immunity threshold has been reached are questions currently being debated ${ }^{14}$. Seroprevalence surveys conducted in major cities such as Mumbai, reported seroprevalence rates above $50 \%$ in slum areas for the first half of July ${ }^{8}$, 
medRxiv preprint doi: https://doi.org/10.1101/2021.03.23.21254092; this version posted March 26, 2021. The copyright holder for this preprint (which was not certified by peer review) is the author/funder, who has granted medRxiv a license to display the preprint in It is made available under a CC-BY-NC-ND 4.0 International license

suggesting that infection spread very quickly over the first few months in certain pockets, but below $20 \%$ in non-slums, showing the epidemic is highly heterogeneous in space. Therefore, the cumulative attack rate in rural areas and smaller cities may be far lower than that reached in major cities. Understanding what has brought the number of cases down in different places in India, and how to interpret the results from serosurveys in terms of the building up of population immunity is key to assess the future dynamics of the epidemic. Although a large proportion of the Indian population may have already been exposed, the circulation of new more transmissible or antigenically different variants, together with possible waning of population immunity over time, can result in the occurrence of new outbreaks. 
medRxiv preprint doi: https://doi.org/10.1101/2021.03.23.21254092; this version posted March 26, 2021. The copyright holder for this preprint (which was not certified by peer review) is the author/funder, who has granted medRxiv a license to display the preprint in It is made available under a CC-BY-NC-ND 4.0 International license.

\section{Methods}

\section{Epidemiological and demographic data}

Data on the number of SARS-CoV-2 confirmed cases and deaths reported daily in Delhi was available from the $14^{\text {th }}$ of March through the covid19india.org website. This is a volunteerdriven, crowdsourced initiative that collates data from several sources, including from the Ministry of Health and Family Welfare (MoHFW) and others. Cases and deaths that had occurred before the $14^{\text {th }}$ of March were reported as cumulative numbers on the first date of the dataset (i.e. $14^{\text {th }}$ March 2020). As we do not know when these cases and deaths occurred, we did not use the data reported on the $14^{\text {th }}$ of March for parameter inference.

We use data from three serosurveys conducted in Delhi ${ }^{3}$. The dates of sample collection, the number of samples tested, the seropositivity rate found, and the reported estimates of sensitivity and specificity of the assay used in each of the three serosurveys are summarised in Table S1.

We use projections of the population in Delhi for 2021 generated by the National Commission on Population ${ }^{15}$ split into age classes of 10 years.

Transmission model

To model SARS-CoV-2 transmission we use a Susceptible-Exposed-Infected-Recovered (SEIR) deterministic transmission model (Figure S7, equations in the Supplementary Material). We 
medRxiv preprint doi: https://doi.org/10.1101/2021.03.23.21254092; this version posted March 26, 2021. The copyright holder for this preprint (which was not certified by peer review) is the author/funder, who has granted medRxiv a license to display the preprint in It is made available under a CC-BY-NC-ND 4.0 International license

do not stratify the population by age with respect to transmission parameters, and therefore assume random mixing by age such that the epidemic growth is equivalent in all age groups. We do not account for births, or deaths due to causes other than COVID-19, because of the short timeframe for the model. The generation time has been estimated at about 6.5 days, with infectiousness typically beginning in the day before symptoms start ${ }^{16,17}$. Given an incubation period of about 5.5 days, ${ }^{18}$ we therefore assumed a mean duration of the latency (pre-infectious period) of 4.5 days and a mean duration of infectiousness of 2 days to give the correct generation time.

Disease progression and death model

We model disease progression and death following infection independently of the transmission process (Figure S7). As the model has been used for other purposes, it also includes hospitalisations, although these are not relevant for the work presented here and do not affect the results.

We use an incubation period (i.e. presymptomatic) with mean of 5.5 days, and a peaked distribution modelled by an Erlang distribution with shape parameter 6 as observed. ${ }^{18}$ We assume that one third of infections are asymptomatic (although there is high variability in the observed proportion across studies ${ }^{19-21}$ and a general increase in the proportion of infected that show symptoms through age $\left.\mathrm{e}^{22,23}\right)$.

The proportion of total infections (asymptomatic and symptomatic) leading to hospitalisation and death are tracked separately - i.e. there is overlap between 
medRxiv preprint doi: https://doi.org/10.1101/2021.03.23.21254092; this version posted March 26, 2021. The copyright holder for this preprint (which was not certified by peer review) is the author/funder, who has granted medRxiv a license to display the preprint in It is made available under a CC-BY-NC-ND 4.0 International license.

compartments for hospitalised individuals and those that will die (fatal infections). The proportion of infections leading to hospitalisation (with critical or non-critical care need respectively) are age-adjusted with the demographics from Delhi and age-stratified estimates from ${ }^{6}$ based on data from China. Similarly, the proportion of infections leading to death (i.e. the age-adjusted IFR) is based on estimates of age-stratified IFR from ${ }^{4}$ applied to the population of Delhi.

The average time from symptom onset to hospitalisation is set to 5.8 days, consistent with observations in China ${ }^{24}$. We assume a mean duration of hospital stay of 9.8 days if no critical care and 9.8 days if critical care required, followed by 3.3 days to recover in non-critical care (stepdown), based on early, unpublished UK estimates. Note these estimates do not affect our results, which are not based on hospitalisations. The average time from symptom onset to death was around 16 days $^{6}$. We therefore assume a mean delay between the time of hospitalisation and death of 10 days. These values may be different for India, but no data is currently available.

\section{Parameter inference}

We fit the transmission model to both the seroprevalence data and the daily incidence of COVID-19 deaths reported between the $15^{\text {th }}$ of March and the $30^{\text {th }}$ of September, 2020. To account for under-reporting and overdispersion on the death data, we model the number of deaths with a Negative Binomial distribution:

$$
\operatorname{deaths}^{o b s}(t) \sim \operatorname{NegBin}(\mu=\theta \times \operatorname{deaths}(t), k)
$$


medRxiv preprint doi: https://doi.org/10.1101/2021.03.23.21254092; this version posted March 26, 2021. The copyright holder for this preprint (which was not certified by peer review) is the author/funder, who has granted medRxiv a license to display the preprint in It is made available under a CC-BY-NC-ND 4.0 International license.

where the mean is $\theta \times$ deaths $(t)$ and the variance is $\theta \times$ deaths $(t)+$ $(\theta \times \text { deaths }(t))^{2} /(\theta \times \text { deaths }(t))^{k}$.

We model the number of individuals that would test seropositive each day with a given serological assay of sensitivity $S e_{j}$ and specificity $S p_{j}$ as

$$
\operatorname{seropositives~}_{j}(t)=\sum_{i=1}^{t-1} e_{i n c}(i) * p_{\text {sero, } j}(t-i)+\left(1-S p_{j}\right) * s_{\text {prev }}(t)
$$

where $e_{i n c}$ is the incidence of infection, $p_{s e r o, j}(\tau)$ is the probability of testing positive $\tau$ days after infection and $s_{\text {prev }}$ is the number of susceptible, as in Ojal et al. ${ }^{25}$. We assume that $p_{\text {sero }, j}(\tau)$ increases linearly from 0 the day of infection to $S e_{j} 26$ days after infection and remains constant after that (i.e. we do not consider seroreversion):

$$
p_{\text {sero }, j}(\tau)=\left\{\begin{array}{c}
\operatorname{Sej} \times \frac{\tau}{26}, \text { if } 0<\tau<26 \\
\text { Sej, if } \tau \geq 26
\end{array}\right.
$$

Finally, we link the modelled number of seropositives at the mid time point of each serosurvey (denoted here by $\mathrm{ts}_{1}, \mathrm{ts}_{2}$ and $\mathrm{ts}_{3}$ respectively for the serosurveys 1,2 and 3 ) to the data from the three seroprevalence surveys using Beta Binomial distributions to account for overdispersion:

$$
\operatorname{seropositives}\left(t_{s j}\right)^{\text {obs }} \sim
$$


medRxiv preprint doi: https://doi.org/10.1101/2021.03.23.21254092; this version posted March 26, 2021. The copyright holder for this preprint (which was not certified by peer review) is the author/funder, who has granted medRxiv a license to display the preprint in It is made available under a CC-BY-NC-ND 4.0 International license.

$$
\operatorname{BetaBinom}\left(N=N_{\text {samples }, j}, p=\operatorname{seropositives~}_{j}\left(t_{s j}\right) / \text { population }, \sigma=1 / 0.7\right)
$$

with the overdispersion parameter fixed to $\sigma=1 / 0.7$, due to the small number of observations available to accurately estimate it.

We allow the reproduction number, $R$, to change at 5 different time points corresponding to the time of changes in interventions (Table S2). We denote $R_{0}$ the basic reproduction number during the first period (i.e. before any changes), and $R_{i}$ the reproduction number after the $\mathrm{i}$-th change and during the $(\mathrm{i}+1)$-th $(\mathrm{i}$ in $1, \ldots, 5)$ period. We parameterise it as $R_{i}=$ $R_{0} \times\left(1+r_{1}\right) \times \ldots \times\left(1+r_{i}\right)$.

We estimate the initial value of the reproduction number $\left(R_{0}\right)$ and the subsequent changes at each time point $\left(r_{1}, \ldots, r_{5}\right)$, the initial number of infected $(E(0)+I(0))$, the reporting $(\theta)$ and overdispersion of deaths $(k)$. We assume the starting time for the simulations, $t_{0}$, to be the $19^{\text {th }}$ of February 2020 (i.e. 28 days before the first ten cases were reported) and estimate the number of infected individuals at that time point $(E(0)+I(0))$.

The first change on the reproduction number, corresponding to the start of the lockdown on the $25^{\text {th }}$ of March (and modelled through the parameter $r_{1}$ ), could not be estimated, because the number of deaths at that time did not allow to infer a change in transmission (no deaths reported between the $15^{\text {th }}$ and the $28^{\text {th }}$ of March). We therefore assumed $r_{1}=$ 0 , and the subsequent change on the reproduction number $\left(r_{2}\right)$ was assumed to occur on the $4^{\text {th }}$ of May, when the first relaxations were introduced. Therefore, the estimate of the 
medRxiv preprint doi: https://doi.org/10.1101/2021.03.23.21254092; this version posted March 26, 2021. The copyright holder for this preprint (which was not certified by peer review) is the author/funder, who has granted medRxiv a license to display the preprint in It is made available under a CC-BY-NC-ND 4.0 International license.

reproduction number between the beginning of the simulations $\left(19^{\text {th }}\right.$ of February 2020$)$ and until the first estimated change on the $4^{\text {th }}$ of May 2020 implicitly accounts for any effects of the lockdown at that time.

Because $R_{0}$ and the initial number of infected are highly correlated, we estimate the total number of infections just before the first change on the reproduction number, on the $4^{\text {th }}$ of May, and back-calculate the initial number of infected using the relationship given by a simple exponential growth model and the relationship between $R_{0}$ and the epidemic growth rate for an SEIR model ${ }^{26}$, as in Salje et al. ${ }^{27}$.

Model parameters were estimated using Markov Chain Monte Carlo via the lazymcmc package ${ }^{28}$ with 100,000 iterations and uniform prior distributions. Four chains with different starting values were run to check convergence.

All the analyses were implemented in R 4.0.2 ${ }^{29}$.

Acknowledgements. We thank Nimalan Arinaminpathy for insightful comments on the manuscript, Marc Baguelin for helpful discussions on parameter inference and James A. Hay for help using the lazymcmc R package. M.P.-S. is a Sir Henry Dale Fellow jointly funded by the Wellcome Trust and the Royal Society (grant number 216427/Z/19/Z). M.P.-S., O.J.W., N.F.B., R.V., and N.C.G. acknowledge funding from the MRC Centre for Global Infectious Disease Analysis (MR/R015600/1), jointly funded by the UK Medical Research Council (MRC) and the UK Foreign, Commonwealth \& Development Office (FCDO), under the MRC/FCDO 
medRxiv preprint doi: https://doi.org/10.1101/2021.03.23.21254092; this version posted March 26, 2021. The copyright holder for this preprint (which was not certified by peer review) is the author/funder, who has granted medRxiv a license to display the preprint in It is made available under a CC-BY-NC-ND 4.0 International license

Concordat agreement and is also part of the EDCTP2 programme supported by the European Union; and acknowledge funding by Community Jameel.

Author contributions. M.P.-S. and N.C.G. designed the study. M.P.-S. performed the analyses and wrote the first draft of the manuscript. N.B. and R.V. provided code for the analysis. All authors critically reviewed the methods, and contributed to the interpretation of the results and writing of the manuscript.

Competing interests. The authors declare no competing interests. 
medRxiv preprint doi: https://doi.org/10.1101/2021.03.23.21254092; this version posted March 26, 2021. The copyright holder for this preprint (which was not certified by peer review) is the author/funder, who has granted medRxiv a license to display the preprint in It is made available under a CC-BY-NC-ND 4.0 International license .

\section{References}

1. Pulla, P. India's epidemic adviser fears coronavirus crisis will worsen. in Nature, Vol. 583180 (Springer, 2020).

2. $\quad$ Chatterjee, P. Is India missing COVID-19 deaths? Lancet 396, 657 (2020).

3. Nandini Sharma, et al. The prevalence and trends of SARS-CoV-2 infection in Delhi: A population-based seroepidemiological study. August-September round. (New Delhi, 2020).

4. Nicholas F Brazeau, et al. COVID-19 Infection Fatality Ratio: Estimates from Seroprevalence. (Imperial College London, 2020).

5. O'Driscoll, M., et al. Age-specific mortality and immunity patterns of SARS-CoV-2. Nature (2020).

6. Verity, R., et al. Estimates of the severity of coronavirus disease 2019: a model-based analysis. Lancet Infect Dis 20, 669-677 (2020).

7. Levin, A.T., et al. Assessing the age specificity of infection fatality rates for COVID-19: systematic review, meta-analysis, and public policy implications. Eur J Epidemiol 35, 1123-1138 (2020).

8. Malani, A., et al. Seroprevalence of SARS-CoV-2 in slums versus non-slums in Mumbai, India. Lancet Glob Health (2020).

9. Clark, A., et al. Global, regional, and national estimates of the population at increased risk of severe COVID-19 due to underlying health conditions in 2020: a modelling study. Lancet Glob Health 8, e1003-e1017 (2020).

10. Cai, R., Novosad, P., Tandel, V., Asher, S. \& Malani, A. Representative Estimates of COVID-19 Infection Fatality Rates from Three Locations in India. medRxiv (2021).

11. Bithika Chatterjee, Rajeeva Laxman Karandikar \& Mande, S.C. The mortality due to COVID-19 in different nations is associated with the demographic character of nations and the prevalence of autoimmunity. (ed. medRxiv) (2020).

12. Parveen Kumar \& Chander, B. COVID 19 mortality: Probable role of microbiome to explain disparity. Medical Hypotheses 144, 110209 (2020).

13. Walker, P.G.T., et al. The impact of COVID-19 and strategies for mitigation and suppression in low- and middle-income countries. Science 369, 413-422 (2020).

14. Chandrashekhar, V. India's COVID-19 cases have declined rapidly - but herd immunity is still far away, scientists say. in Science (2020).

15. Census of India 2011. Population projections for India and states 2011-2036: report of the technical group on population projections. November 2019. Available at https://nhm.gov.in/New Updates 2018/Report Population Projection 2019.pdf. (National Commission on Population, Ministry of Health and Family Welfare, 2019).

16. Nishiura, H., Linton, N.M. \& Akhmetzhanov, A.R. Serial interval of novel coronavirus (COVID-19) infections. International Journal of Infectious Diseases (2020).

17. $\mathrm{Bi}, \mathrm{Q}$., et al. Epidemiology and transmission of COVID-19 in Shenzhen China: analysis of 391 cases and 1,286 of their close contacts. Lancet Infect Dis 20, 911-919 (2020).

18. Lauer, S.A., et al. The incubation period of coronavirus disease 2019 (COVID-19) from publicly reported confirmed cases: estimation and application. Annals Internal Med, https://doi.org/10.7326/M7320-0504 (2020).

19. Oran, D.P. \& Topol, E.J. The Proportion of SARS-CoV-2 Infections That Are Asymptomatic : A Systematic Review. Ann Intern Med (2021). 
medRxiv preprint doi: https://doi.org/10.1101/2021.03.23.21254092; this version posted March 26, 2021. The copyright holder for this preprint (which was not certified by peer review) is the author/funder, who has granted medRxiv a license to display the preprint in It is made available under a CC-BY-NC-ND 4.0 International license

20. Sarah Beale, Andrew Hayward, Laura Shallcross, Robert W Aldridge \& Fragaszy, E. A Rapid Reviewand Meta-Analysisof the Asymptomatic Proportion of PCR-Confirmed SARS-CoV-2 Infections in Community Settings. medRxiv.

21. Buitrago-Garcia, D., et al. Occurrence and transmission potential of asymptomatic and presymptomatic SARS-CoV-2 infections: A living systematic review and metaanalysis. PLoS Med 17, e1003346 (2020).

22. Davies, N.G., et al. Age-dependent effects in the transmission and control of COVID19 epidemics. Nat Med 26, 1205-1211 (2020).

23. Piero Poletti, et al. Probability of symptomsand critical disease after SARS-CoV-2 infection. arxiv (2020).

24. Katy Gaythorpe, et al. Report 8: Symptom progression of COVID-19. (Imperial College London, 2020).

25. John Ojal, et al. Revealing the extent of the COVID-19 pandemic in Kenya based on serological and PCR-test data. (ed. medRxiv) (2020).

26. Wallinga, J. \& Lipsitch, M. How generation intervals shape the relationship between growth rates and reproductive numbers. Proc Biol Sci 274, 599-604 (2007).

27. Salje, H., et al. Estimating the burden of SARS-CoV-2 in France. Science 369, 208-211 (2020).

28. Hay, J.A. lazymcmc R package (2020).

29. R Core Team. R: A Language and Environment for Statistical Computing. $R$ Foundation for Statistical Computing. (Vienna, Austria, 2020). 
medRxiv preprint doi: https://doi.org/10.1101/2021.03.23.21254092; this version posted March 26, 2021. The copyright holder for this preprint (which was not certified by peer review) is the author/funder, who has granted medRxiv a license to display the preprint in It is made available under a CC-BY-NC-ND 4.0 International license.

Figures

Figure 1. Epidemic of COVID-19 in Delhi. Daily number of COVID-19 reported cases (light blue) and deaths (dark blue) between the $15^{\text {th }}$ of March and the $31^{\text {st }}$ of December, 2020 in a logarithmic scale. The grey dashed vertical lines indicates the end of the study period $\left(30^{\text {th }}\right.$ of September 2020).

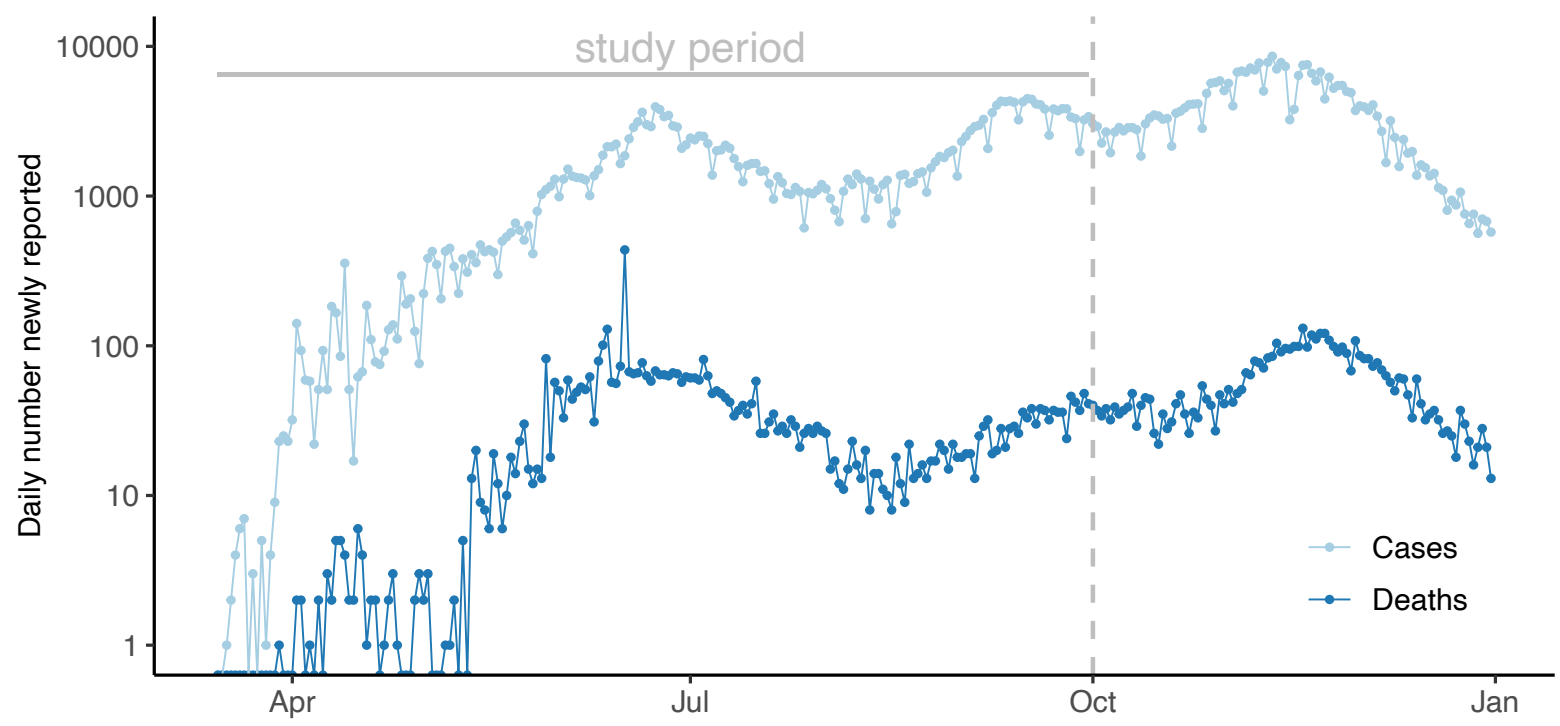


medRxiv preprint doi: https://doi.org/10.1101/2021.03.23.21254092; this version posted March 26, 2021. The copyright holder for this preprint (which was not certified by peer review) is the author/funder, who has granted medRxiv a license to display the preprint in It is made available under a CC-BY-NC-ND 4.0 International license.

Figure 2. Model fit to data. (a) Model fit to the time-series of reported deaths (points), with $50 \%$ and $95 \%$ credible intervals $(\mathrm{Crl})$. The last six points shown in gray were not used for parameter inference. (b) Median and 95\% Crl model fit to seroprevalence data (gray) from three serosurveys.

a)

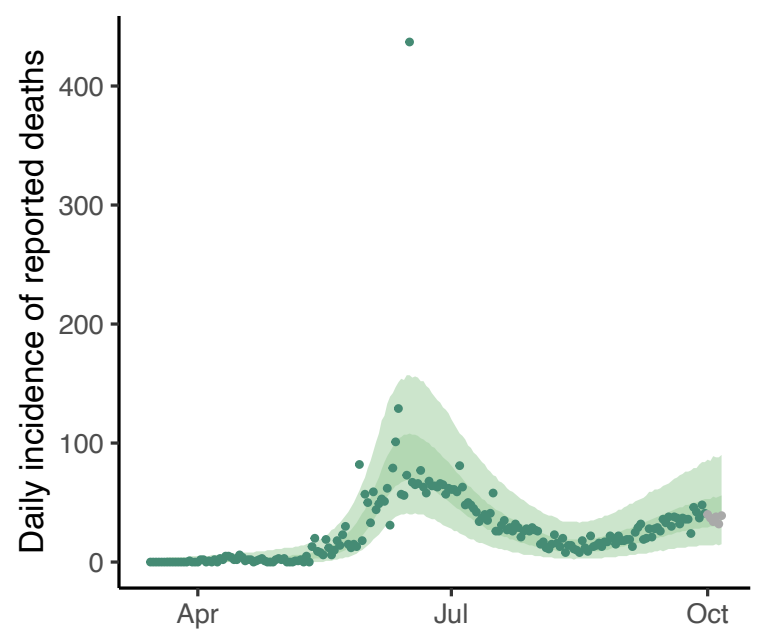

b)

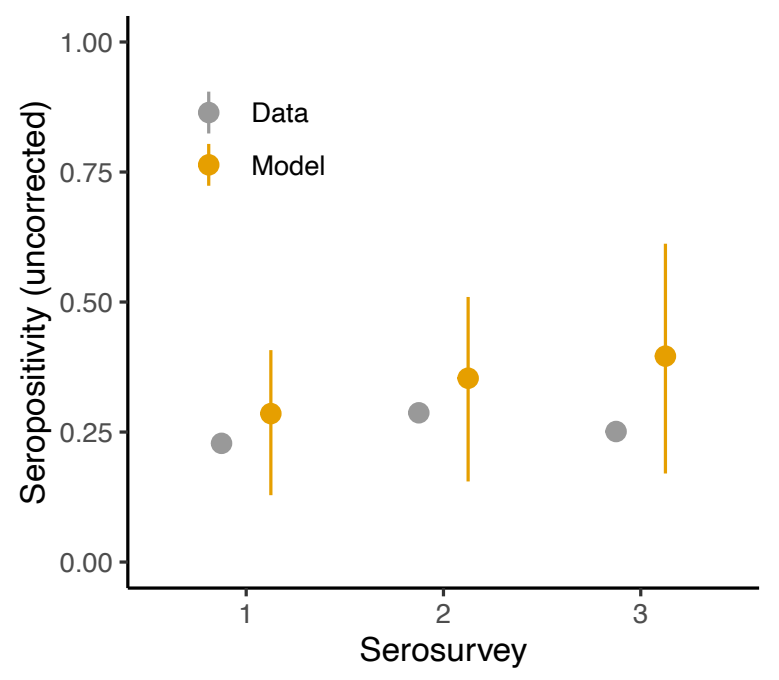


medRxiv preprint doi: https://doi.org/10.1101/2021.03.23.21254092; this version posted March 26, 2021. The copyright holder for this preprint (which was not certified by peer review) is the author/funder, who has granted medRxiv a license to display the preprint in It is made available under a CC-BY-NC-ND 4.0 International license.

Figure 3. Effective reproduction number and attack rate. (a) Median and 50\% and $95 \% \mathrm{Crl}$ of the estimated reconstructed effective reproduction number. Changes are assumed to occur when changes in the interventions were introduced. (b) Median and $50 \%$ and $95 \% \mathrm{Crl}$ of the estimated reconstructed infection attack rate.

a)

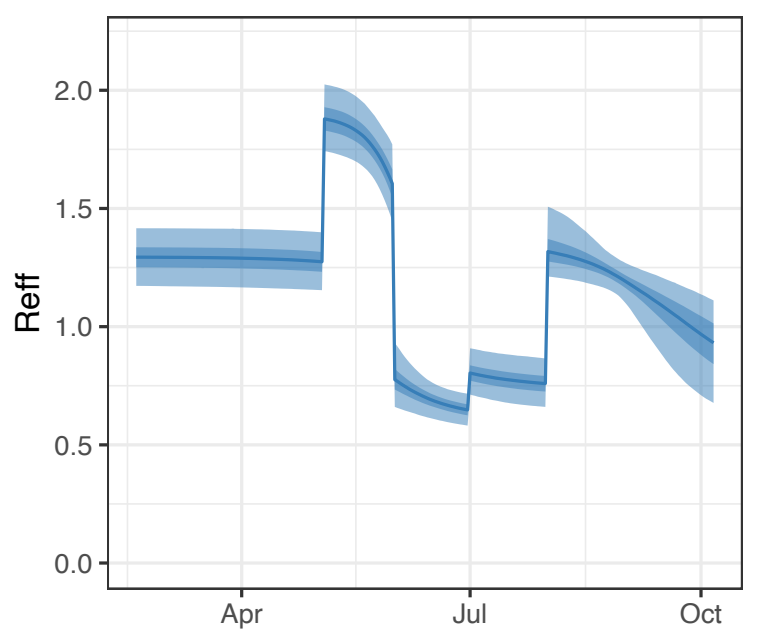

b)

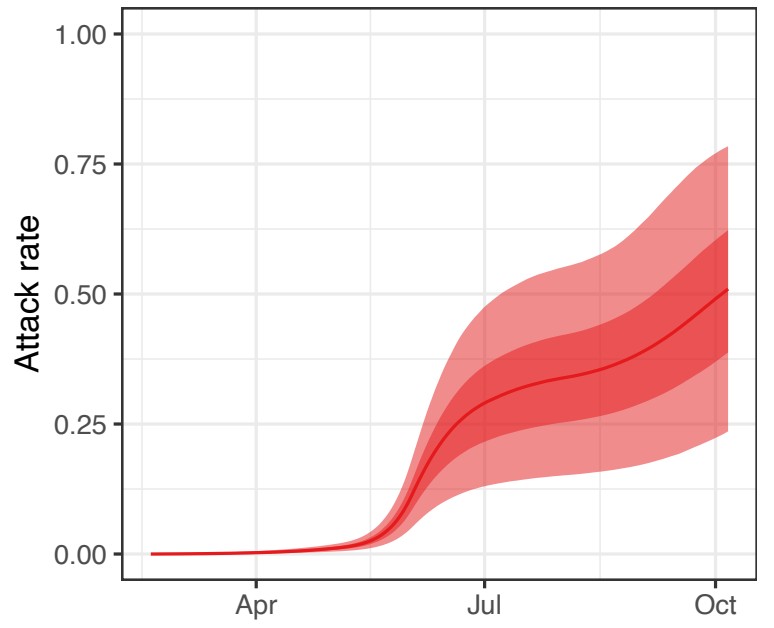


medRxiv preprint doi: https://doi.org/10.1101/2021.03.23.21254092; this version posted March 26, 2021. The copyright holder for this preprint (which was not certified by peer review) is the author/funder, who has granted medRxiv a license to display the preprint in It is made available under a CC-BY-NC-ND 4.0 International license.

Figure 4. Detection of infections. (a) In orange, $50 \%$ and $95 \% \mathrm{Crl}$ of the incidence of symptomatic infections, assuming that $2 / 3$ of all infections are symptomatic. In black, the daily number of newly reported cases. (b) $50 \%$ and $95 \% \mathrm{Crl}$ of the estimated detection probability per symptomatic infection per day.

a)

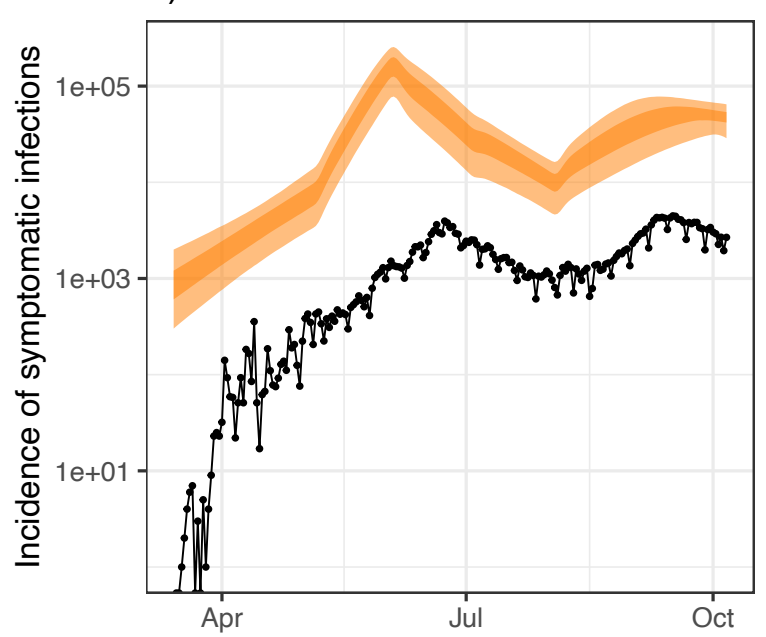

b)

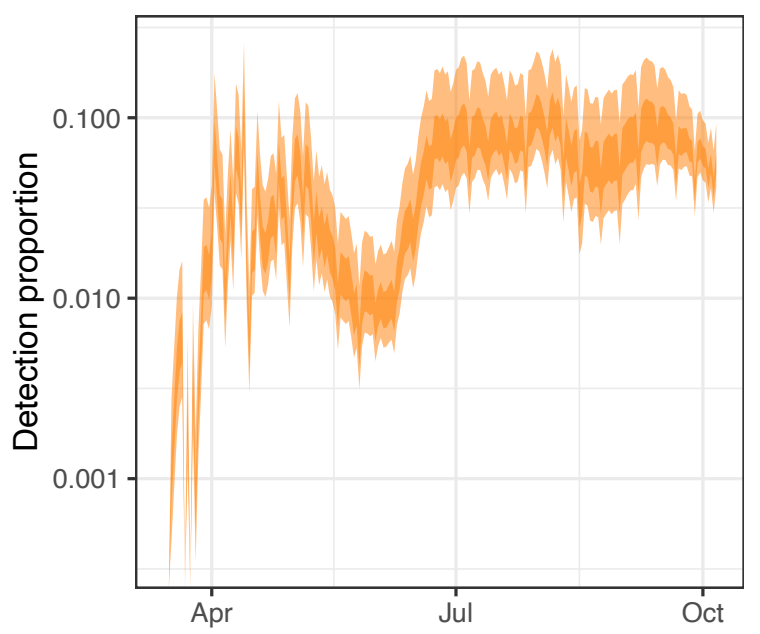

